\title{
THE DEVELOPMENT APPLICATION OF PASURUAN LOCAL CULTURE AS MOBILE INTERACTIVE LEARNING MEDIA OF DECORATIVE MATERIAL IN PASURUAN
}

\author{
Rizki Amalia Putri' ${ }^{1}$, Warih Hadayaningrum² \\ ${ }^{1}$ Universitas Negeri Surabaya \\ ${ }^{2}$ Universitas Negeri Surabaya \\ 1'amalovelyc3@gmail.com, ${ }^{2}$ warihsendratasik@yahoo.com
}

\begin{abstract}
The developement of application media with learning materials is very necessery, the increase use technology in daily life. There is lack of applications with the theme of education in accordance with learning. Mobile phones are not used as learning media by teachers and students. The reverence of learning material and learning media makes research on technology education need to be raised as a matter of matter in the field. There are known from the results of research with a sample consiting of student and teachers of art and culture. The result are known from the trial research with the pretest and postest, questionnaire activities and calculated with the T-thest formula. The development of the local cultural application of Pasuruan has become one of the mobile interactive learning that can be used as a medium for learning revision. The development process is carried out through the 4D stages, which are define, design, develop and dessemine. The results of the research using media applications is effectif for learning. In addition, the results of the validator shows decent results as products which can be used. The respond of teacher and student show satisfied result in using Pasuruan local culture application as learning media.
\end{abstract}

Keywords: application, interactive, learning, media,

\begin{abstract}
Abstrak
Pengembangan media aplikasi dengan materi pembelajaran sangat diperlukan, dengan semakin meningkatkan penggunaan teknologi. Minimnya aplikasi dengan tema pendidikan sesuai dengan pembelajaran sehingga handphone tidak digunakan sebagai media belajar oleh guru dan siswa. Reverensi materi belajar dan media belajar menjadikan penelitian bertema teknologi pendidikan perlu untuk diangkat sebagai bahan permasalahan di lapangan. Hal ini diketahui dari hasil penelitian dengan sampel yang terdiri dari siswa dan guru mata pelajaran seni budaya. Hasil diketahui dari penelitian ujicoba, dengan kegiatan quisioner, pretest dan postest serta dihitung dengan rumus T-test. Pengembangan aplikasi budaya lokal Pasuruan menjadi salah satu media pembelajaran interaktif mobile yang dapat menjadi media reverensi belajar. Proses pengembangan yang dilakukan melalui tahapan 4D yaitu define, design, develop dan dessemine. Berdasarkan hasil penelitian diketahui bahwa belajar menggunakan media aplikasi dikategorikan efektif, meningkatkan hasil belajar pada ranah kognitif pada materi yang diangkat. Hasil validator menunjukkan aplikasi layak sebagai produk yang digunakan dalam belajar. Respon guru dan respon siswa menunjukkan hasil yang memuaskan dengan kategori sangat layak dalam penggunaan aplikasi budaya lokal Pasuruan sebagai media belajar.
\end{abstract}

Kata Kunci: aplikasi, interaktif, pembelajran, media

\section{INTRODUCTION}

Learning media develops rapidly and vary following the development of era. Learning to use technology as a distributor of information also varies from the use of computers, laptops, tablet screens, mobile phones and or devices. Information seeking and learning activities are also developing along with the flow of technology. Studying at school and outside of school are now more flexible in terms of time and place. Through internet sources, students can access 
various things outside the lessons, ao that more knowledge is absorbed. This is in accordance with the goal of the government in the use of learning resources. In line with the thinking of (Tajjudin, 2015), (Andi, 2015) and (Kuswanto et al., 2017), "students are required to study independently so that they can explore their interests and potential".

The use of device technology is the most widely owned and used means. It was known through (Agus Tri Haryanto - detikInet, n.d.; Kompas, 2016; Media Websindo, 2019; Websindo, 2019c, 2019a, 2019b) and the APJII (Asosiasi Penyelenggara Jasa Internet Indonesia) agency in 2019 through the Lipsus website that $91 \%$ of mobile phone use is known. This large number is known to be dominated by the age of 15-19 years as the most internet users. Learning to use mobile phones in learning among students can be effective. It is ecause at the age of 15-19 is the age of students or learners. That supported by research, (Setyadi et al., 2019) said "student in this century prefer to use electronic devices such as cellphone or laptop".

Mobile application can become an effective learning media. the use of information is more accessible and flexible. Unfortunately, the use of applications as learning media in schools is still minimum. Likewise, with the content of materials related to school learning related to the curriculum, Especially material related to the art of local cultures, It is known through the search for playstore accounts, the application which appears most is the application of pictorial stories and children's games. Through APJII, it is also known that the use of mobile phones is mostly used as social media-entertainment such as sending messages, watching videos and searching songs

In Pasuruan, the use of mobile phones is worried that it will disrupt learning activities. Rizal's Counseling teacher said "cellphone abuse in learning at school often occurs, so students are not focused. Classroom learning can be disrupted by students' use of mobile phones, when mobile phones are really not needed. Students become less conducive or lack concentration in learning "(interview, counseling teacher, SMPN 1 Gondangwetan).

Learning media using mobile phone is still lack. In fact, learning media can increase student interest in learning. There needs to be more reference regarding learning media with mobile phones, such as application. According to (Sasmitatias \& Kuswanto, 2018), it is necessary to develop applications as educational learning both in character and skill. This is also in line with the thoughts of (H. Iksan \& Mohd Saufian, 2017) that learning research that elevates the media, abilities and characters that need to be developed. In addition to the need 
for learning local culture, (Sartini, 2004) states that "Local culture is understood at the local thought which is a wise, full of wisdom, good value, rooted, and followed by many people".

The lack of instructional media as a reference by both teachers and students are one of the obstacles in learning. Students are dominated by the use of books in learning and the teacher explains in front of the class. (Setiaji, 2016), "Student learning activities by listening to teacher explanations are less effective in absorbing material. Students are much more effective learning by remembering and doing activities such as listening, seeing and practicum simultaneously ". Yet, according to (Akhwani, 2019), it is known that the use of learning media is very important and influences learning outcomes, but unfortunately the use of interactive multimedia is still minimal and its use is little to be conducted by learners. The results of student interviews also found that there is a great desire to learn to use interactive media in learning at school or outside school.

Learning with application based on a previous research, (Aprianto \& Handaga, 2016) "Through the android application the information obtained is more effective and efficient to be absorbed". (Websindo, 2019b) also said that mobile learning can provide opportunities for students to interact, information obtained by interesting and easy to understand. In addition through student learning, applications can increase learning interest, learning activities in which there is feedback in learning activities and can apply learning by looking at the tutorial of the application. (As-Syifa, 2018; Sanjaya, 2009) said the use of learning media can help students better understand this material. It is in accordance with the research of (Novita \& Harahap, 2020; Nurhidayat et al., 2020)"there is a 70\% increase in learning and more information is absorbed with longer memory". (Son et al., 2016) stated that learning using interactive multimedia can improve learning compared to learning in the traditional way using books.

According to the on interviews with teachers and observations in the Pasuruan region, it can be seen that the problem is that the facilities owned by schools at least have computer technology, LCV, VCD and Projectors. Unfortunately, learning using the existing media in schools did not meet the number of classes and students. Thus, the use of facilities was carried out in rotation while teachers dis not like the use of mobile phones in learning in the classroom.

The lack of learning media is one of the obstacles for students and teachers, especially in SMPN 1 Gondangwetan. Students who tend to be passive make the teacher defeat in learning. So that applications with learning elements need to be improved and make more study 
reverence. The prevalence of learning media that concurrently pictures, writing and video are also lacking. Based on the problem of using learning media can be seen the following table 1 .

Table 1. Analysis of Learning Implementation at School

\begin{tabular}{clc}
\hline No & \multicolumn{1}{c}{ Question } & Implementasi \\
\hline 1 & Learning using book at school & $93 \%$ \\
2 & Learning using computer at school & $40 \%$ \\
3 & Learning using internet at school & $41 \%$ \\
4 & Learning using mobile phoneat school & $40 \%$ \\
5 & The relationship between art and culture curriculum with Pasuruan's & $65 \%$ \\
& local culture at school & $67 \%$ \\
6 & Information and intruduction to Pasuruan local culture through books & $53 \%$ \\
7 & Information and intruduction to Pasuruan local culture through video & \\
8 & Information and intruduction to Pasuruan local culture through & $62 \%$ \\
& picture & $38 \%$ \\
9 & The use of mobie phone to learning Pasuruan local culture & $47 \%$ \\
\hline
\end{tabular}

Based on table 1, it is known that was unfortunate, because $100 \%$ of all teachers in the Pasuruan region dominate the use of books in class as learning mediaThe use of mobile technology as learning was only $40 \%$ and learning related to local culture only reached $38 \%$. Based on students, learning in class is not interesting. Thus, they easily got bored. Students wanted learning which was different, practical outside the classroom, using a variety of learning media in addition to learning with books. From the problems that have been explained, it can be seen the formulation of the problem, which are 1) how is the process; 2) how is the quality; 3)how is the effectiveness of research.

\section{METHOD}

This research is a development research. The approach taken in this research was the R\&D approach. Research by R\&D (Dr.Sugiyono, 2017; Thiagarajan, 1974) The R\&D development consists of the stages of define, design, dessemine and development. The define stages are carried out with analysis of learning material, analysis of learning media, analysis of learning concepts and learning objectives. The design stage is carried out by compiling material ideas that are used for concept development, considering and optimizing the material, media, format selection. Stages develop conducted by making samples of products in the form of storyboards and prototypes, then realized to be done at a later stage trials. The dessemine phase is carried out by distributing products, the distribution is carried out for teachers and students. Trial stage done twice: through pretest and posttest on students as much as 30 to assess the 
effectiveness of learning. Quality development is carried out with validation by subject matter experts, media, language, media and grapict and tested on teachers and students to study the response.

The research was conducted trials in schools which had problems in learning. At SMPN 1 Gondangwetan, a trial was carried out by conducting questionnaires, interviews, observations and documentation. Student learning outcomes need to be known to find an increase in learning before and after using the application as learning media. Researchers used one class as a research sample of 30 students. Students would do a pretest and posttest and the results would be analyzed by using the T-test formula with the help of the SPSS application. Provision of questions tailored to the implementation of the available curriculum.

Research source of mobile interactive learning development of application with decorative art subject was conducted by collecting information through questionnaires, interviews, field observations and documentation. Interviews were conducted on a number of students, teachers, batik artisans in the Pasuruan region (Pasuruan Batik Expert). Observations were also made at schools and tourism sites which contained temples as part of the collection of ornamental material data related to Pasuruan Local Cultural Arts. The distribution of questionnaires was carried out to determine the needs of problems in the field, and to find out the quality response and effectiveness of the application. Questionnaires were distributed at area schools in Pasuruan.

\section{RESULTS AND DISCUSSION}

\section{Results}

\section{Application Development Process}

Application development was carried out with the stages of define, design, develope and desseminate.

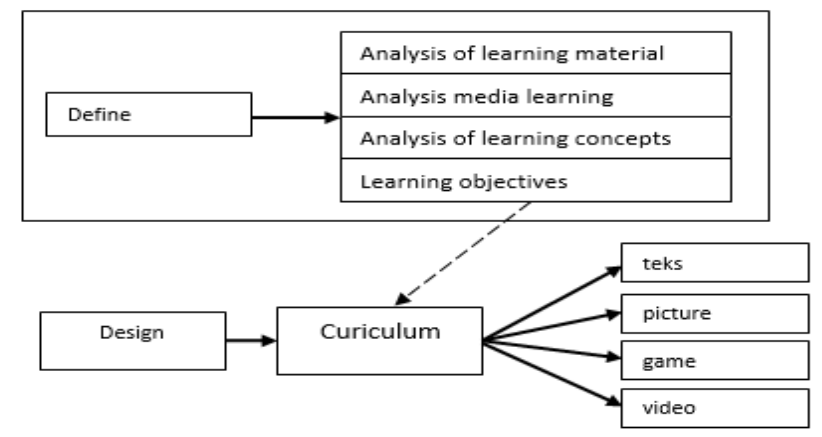

Figure 1. Draft/Design of Application 
In defining stage, it was conducted the needs off analysis, which was carried out with a lift deployment to determine the needs in the field in order to make application products. Need analysis consists of concept analysis, material analysis, media analysis and learning objectives. It is known that learning ornamental diversity with local culture is still minimal taught at only $41 \%$. After the concept of material, the media and the purpose of the problem are known to be continued at the design stage of application design.

At the design stage, consideration is made to choose the right format to attract learners. It gave priority to learning curriculum as materials available in the application, then the appropriate format was determined as learning media. In the design stage, the application included elements of writing, images, games and videos that are adapted to decorative arts and culture. The further stage was product development and dissemination.

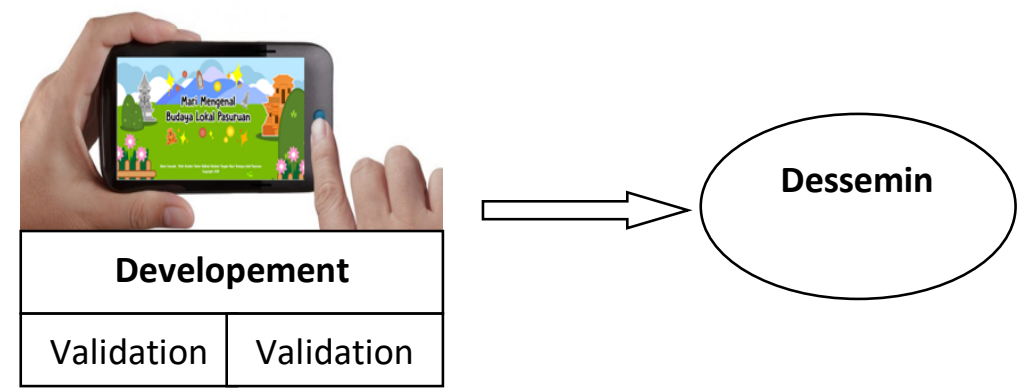

Figure 2. stages of developmenta and desseminate

The development stage validation was carried out by expert experts in their fields. Validation had been submitted twice. Validations included media validation, graphic validation, material validation and language validation. After the validation process had been carried out and reached a satisfactory value the next step is deployment. The dissemination process was carried out at SMPN Gondangwetan 1 in class VII with 30 students in one class.

The dissemination process was conducted to determine the quality of the application and determine student learning outcomes to determine the effectiveness of learning to use applications that have been made. In addition, the dissemination was conducted on teachers in the Pasuruan District of Art and Culture Subject.

\section{The Quality of Application Based on Product Validity Result}

The development of application was conducted through validation stage by experts to find out the quality of the product that has been made. Validation was presented twice. The first validation was conducted after the new product had been made. The first validation was conducted to determine the shortcomings of the product. Thus, it could be revised to be better and more perfect. The second validation was the final validation which was carried out by 
adjusting the revision to the previous validation. Validation was carried out by distributing questionnaires to each expert consisting of mastery validation, language validation, media validation and graphic validation. Following table is the final results of the validation carried out for the application product.

Table 2. Recapitulation of expert validation

\begin{tabular}{cc}
\hline Validator & Pecentage (\%) \\
\hline Material expert & $92,5 \%$ \\
Language expert & $100 \%$ \\
Media expert & $98 \%$ \\
Kegrafikaan expert & $97 \%$ \\
\hline Average & $96,8 \%$ \\
\hline
\end{tabular}

Based on table 2, it is known that the validation results for the mobile learning media of Pasuruan local culture application are $92.5 \%$ material validation, $100 \%$ language validation, $98 \%$ media validation and $97 \%$ graphic validation. If it was averaged as a whole, there was a value of $96.8 \%$. It means that the Pasuruan local culture application is included in the excellent category and suitable for use without going through additional revisions.

\section{The Wisdom of Application based on Trial}

After application had been eligible or suitable for use, the next process was distributing stage. The distribution was carried out at SMPN 1 Gondangwetan. Besides introducing the application that had been made, The researcher also tested the effectiveness of the application. It was by measuring the ability of students before and after using the application as a mobile learning media. To measure students' abilities, tests were conducted with cognitive aspects in understanding the material before and after using the application. Furthermore, the psychomotor aspect was carried by knowing the ability to practice drawing. The following are the results of the activity of knowing the effectiveness of the application.

Table 3. The trial results to find out the effectiveness of the application as learning.

\begin{tabular}{ccc}
\hline Aspect & Pecentage Pretes (\%) & Pecentage Posttes (\%) \\
\hline Cognitive & $60 \%$ & $88 \%$ \\
Psychomotor & $40 \%$ & $78 \%$ \\
\hline
\end{tabular}

Based on table 3, it is known that there was an increase before and after using the application as learning. In learning with the cognitive aspects of students, there was an increase in answering the questions given. Whereas in psychomotor activities, after students use the 
application, they could practice with more confidence, they did not hesitate and have a goal to complete the decoration.

\section{Efectiveness of Aplication}

Based on students' learning outcome through pretest and posttest, it can be known the effectiveness of learning through the formulation of T-Test. The first learning outcomes, students did not use the application, after that the assessment of learning outcomes was reconducted after students use the application. The following are the results of T-test calculations with the help of the SPSS application.

Table 4. Paired Samples statistics

\begin{tabular}{llllll}
\hline & Mean & N & $\begin{array}{l}\text { Std. } \\
\text { Deviation }\end{array}$ & $\begin{array}{l}\text { Std. Error } \\
\text { Mean }\end{array}$ \\
\hline Pair 1 & Pretest & 60.13 & 30 & 12.451 & .225 \\
& posttest & 88.47 & 30 & 9.273 & 203.875 \\
\hline
\end{tabular}

Table 5. Paired Samples Correlations

\begin{tabular}{lllll}
\hline & N & Correlation & Sig. \\
\hline Pair 1 & $\begin{array}{l}\text { Pretest and } \\
\text { posttest }\end{array}$ & 30 & .420 & .021 \\
\hline
\end{tabular}

Table 6. Paired Samples test

\begin{tabular}{|c|c|c|c|c|c|c|c|c|c|}
\hline & & \multirow[b]{2}{*}{ Mean } & \multirow{2}{*}{$\begin{array}{l}\text { Std. } \\
\text { sDeviation }\end{array}$} & \multirow{2}{*}{$\begin{array}{l}\text { Std. Error } \\
\text { Mean }\end{array}$} & \multicolumn{2}{|c|}{$\begin{array}{c}95 \% \text { Confience } \\
\text { interval of the } \\
\text { difference }\end{array}$} & \multirow[b]{2}{*}{$t$} & \multirow[b]{2}{*}{ df } & \multirow{2}{*}{$\begin{array}{l}\text { Sig. (2- } \\
\text { failed) }\end{array}$} \\
\hline & & & & & lower & upper & & & \\
\hline $\begin{array}{l}\text { Pair } \\
1\end{array}$ & $\begin{array}{l}\text { Pretest and } \\
\text { posttest }\end{array}$ & -28.333 & 12.001 & 2.191 & -32.815 & -23.852 & -12.931 & 29 & .000 \\
\hline
\end{tabular}

If $\alpha=0.05$ and Sig. 0.000 then Sig. $<$ A so that it can be seen that there is a correlation and it is known that there are differences in values that determine effectiveness. Then Sig. $<\mathrm{A}$ is $0.000<0.05$, it can be concluded that the results of the calculation of T-tests conducted by students in the pretest and posttest learning outcomes that there are correlations and there are significant differences. This means that the application used in the test has effectiveness as a learning medium for learning outcomes.

Table 7. Recapitulation of Application usage response

\begin{tabular}{ccl}
\hline Respodents & Pecentage $(\%)$ & Category \\
\hline Students & $86 \%$ & Excellent \\
teacher & $86 \%$ & Excellent \\
\hline average & $86 \%$ & Excellent \\
\hline
\end{tabular}


Based on the results of the responses of the use of applications by teachers and students in table 7, it can be seen that the results of mobile interactive media products in the form of applications has satisfying categories. From the satisfying category with a percentage of $86 \%$, it can be concluded that the application is suitable for use as a learning of art, culture, and decorative materials.

Table 8. Result Recapitulation of the use of application based on aspect

\begin{tabular}{c|c|c}
\hline Aspect & Pecentage (\%) & Category \\
\hline Cognitive & $88 \%$ & Excellent \\
\hline Psychomotor & $78 \%$ & Excellent \\
\hline Average & $86 \%$ & Excellent \\
\hline
\end{tabular}

According to table 8. the recapitulation results of application use can be known the average application usage based on cognitive and psychomotor aspects of $86 \%$. The percentage obtained in using the application was included in the excellent category. Thus, it can be concluded the use of applications can improve cognitive and psychomotor aspects of learning outcomes.

\section{Discussion}

Application development was carried out with the stages of define, design, develope and desseminate. The interactive development research in the form of application products as the final result can be seen that the application can be used as a learning medium. Based on Table 7 and Table 8, it is known that the application can improve the learning of ornamental materials and practices. The application is also worth using because it has a very good category. In addition, based on the results of calculations using the T-Test formula (table 4, 5 and 6), it is known that effective application is used to improve student learning outcomes in decorative arts and culture.

Based on the results of learning effectiveness and student responses, the results of the pilot activities are in accordance with the purpose of application development. There is an increase in the learning of arts and culture materials and practical activities that are easily followed by students. Research by (Nurhidayat et al., 2020; Saputri et al., 2018; Suluh, 2018) also explained that the results of learning with media technology-based mobile applications on smartphones included in the category of very effectively used as a learning tool. Moreover according to the statement (Aprianto \& Handaga, 2016) that the application provides an easy way of learning and incoming information. It is also consistent with the statement (Kuswanto 
et al., 2017) said that mobile learning can provide opportunities for students to interact, information Obtained by interesting and easy to understand.

Learning with applications is one of the uses of technology. In this development known the quality and effectiveness of learning according to the learning management. In accordance with the needs of current students, education 4.0 meets innovative criteria. (Rahardja et al., 2020) said that aids student in getting knowledge is a technology, and the development of this mobile application is one of the innovations in helping students learn art and culture subjects. In addition (Sinlarat, 2016b, 2016a) states the era of learning 4.0 allows a way of learning that are not only read, but has other aspects. The aspects provided in learning with this mobile application have been adapted to the management of learning and consist of visual, audio, verbal text aspects and are connected to the network or link learning resources according to art and culture material.

Meanwhile, if the mobile interactive development associated with literacy. New literacy consists of data literacy, technological literacy and human literacy. (Yamin \& Syahrir, 2020) revealed that these three things if fulfilled it is said to be a new literacy learning. Development of data applications including in literacy, technology literacy and literacy humans. Literacy of data obtained through the activities of students to read, analyze and use information through digital activities with resource materials provided therein. Technological literacy that users perform activities related to the tools of the development so that there is reciprocity, it is seen once in the game menu and quis. While literacy is a human link between students and teachers. Activity using the application do with the supervision of teachers, since activities can be tailored to the learning school. (Ibda, 2018) explained the importance of literacy learning opportunities and challenges of the era pendidikandi 4.0 berbasi literacy and digital competences possessed and teachers.

Combining based learning online / digital with mixed of physical learning or face to face learning, application development is one of the innovation era Blended learning as a solution 4.0 (Lase, 2019). The importance of technology innovation in an era with the increased need for alignment of learning with the times, plus another in the era of the current pandemic. Interactive development of mobile application is very supportive of innovation 4.0 current era.

\section{CONCLUSION}

Based on analysis result and findings, it can be concluded that the developmentof Pasuruan local culture application is effective to use as leaning media for Culture and Art 
subject for decorative material. The product development process is carried out in four stages in accordance with the 4D development method by Thiagarajan (1974).

The quality of the application as a learning medium for decorative materials based on the results of validation by experts in table 2 shows that the product is very suitable for use. Likewise, with student responses and teacher responses, this application has a very good response and is declared worthy of use as a learning medium.

The effectiveness of the application of Pasuruan local culture based on trials at SMPN 1 Gondangwetan obtained very satisfying results after using the product as a learning medium. This is also proved by the results of the T-test to determine the effectiveness of the product.

It is expected that the development of this interactive mobile application product will become a reference material which can be used at schools. Besides, it can be used as a learning media reference by both teachers and students. Hopefully, more research will raise the development of mobile interactive media which can assist students and teachers in learning so that education is better.

\section{ACKNOWLEDGMENTS}

Thanks to Tri Kusumarini for funding this research, the Pasuruan Regency Tourism Office for all the information provided, as well as support from friends and UNESA lecturers.

\section{REFERENCES}

Agus Tri Haryanto - detikInet. (n.d.). Pengguna Internet Indonesia Didominasi Milenial. Retrieved September 3, 2020, from https://inet.detik.com/telecommunication/d4551389/pengguna-internet-indonesia-didominasi-milenial

Akhwani, A. (2019). Strategy Of Digital Etiquette Education Of Elementary School Students. PrimaryEdu - Journal of Primary Education, 3(2), 43. https://doi.org/10.22460/pej.v3i2.1378

Andi, P. (2015). Panduan Kreatif Membuat Bahan Ajar Inovatif (4th ed.). Diva Press.

Aprianto, D., \& Handaga, I. B. (2016). Aplikasi Pengenalan Tokoh Wayang Kulit dan Lagu Jawa Interaktif Berbasis Android Naskah Publikasi.

As-Syifa, D. (2018). Media Pembelajaran. https://doi.org/10.31227/osf.io/34rhg

Dr.Sugiyono, P. (2017). penelitian \& pengembangan (Research and Development/R\&D). Alfabeta. $\quad \mathrm{https}$ //cvalfabeta.com/product/metode-penelitian-dan-pengembanganresearch-and-development/

H. Iksan, Z., \& Mohd Saufian, S. (2017). Mobile Learning: Innovation In Teaching And Learning Using Telegram. IJPTE: International Journal of Pedagogy and Teacher Education, 1(1). https://doi.org/10.20961/ijpte.v1i1.5120

Ibda, H. (2018). Penguatan Literasi Baru pada Guru Madrasah Ibtidaiyah dalam Menjawab 
Tantangan Era Revolusi Industri 4.0. Journal of Research and Thought of Islamic Education, 1(1), 1-21. www.kemdikbud.go.id/main/blog/2016/05/tiga-pilar-hadapiperubahan-

Kompas. (2016). Pengguna Internet Indonesia Didominasi Remaja. 2009. https://inet.detik.com/telecommunication/d-4551389/pengguna-internet-indonesiadidominasi-milenial

Kuswanto, J., Walusfa, Y., Artikel, S., Korespondensi, A., Ratu Penghulu No, J., Sari, K., Baru, T., Raja Tim, B., Ogan Komering Ulu, K., \& Selatan, S. (2017). Pengembangan Multimedia Pembelajaran pada Mata Pelajaran Teknologi Informasi dan Komunikasi Kelas VIII. Innovative Journal of Curriculum and Educational Technology IJCET, 6(2), 58-64. https://journal.unnes.ac.id/sju/index.php/ujet

Lase, D. (2019). Pendidikan di Era Revolusi Industri 4.0. SUNDERMANN: Jurnal Ilmiah Teologi, Pendidikan, Sains, Humaniora Dan Kebudayaan, 1(1), 28-43. https://doi.org/10.36588/sundermann.v1i1.18

Media Websindo. (2019). Indonesia Digital 2019. Websindo. https://websindo.com/indonesiadigital-2019-mobile/

Novita, R., \& Harahap, S. Z. (2020). Pengembangan Media Pembelajaran Interaktif Pada Mata Pelajaran Sistem Komputer DI SMK. 8(1).

Nurhidayat, B., Wedi, A., \& Praherdhiono, H. (2020). Pengembangan Multimedia Mobile Learning Berbasis Smartphone Android Materi Huruf Madura untuk SD Negeri 1 Perante Kabupaten Situbondo. JINOTEP (Jurnal Inovasi Dan Teknologi Pembelajaran): Kajian Dan Riset Dalam Teknologi Pembelajaran, 6(2), 103-110. https://doi.org/10.17977/um031v6i22020p103

Rahardja, U., Lutfiani, N., Harahap, E. P., Wijayanti, L., Universitas Raharja, D., Raharja, D. U., \& Raharja, M. U. (2020). iLearning: Metode Pembelajaran Inovatif di Era Education 4.0. Technomedia Journal (TMJ, 4(2).

Sanjaya, W. (2009). Strategi Pembelajaran Berorientasi Standar Proses Pendidikan. http://www.litbang.kemkes.go.id:8080/handle/123456789/62446

Saputri, D. Y., Rukayah, R., \& Indriayu, M. (2018). Need Assessment of Interactive Multimedia Based on Game in Elementary School: A Challenge into Learning in 21st Century. International Journal of Educational Research Review, 3(3), 1-8. https://doi.org/10.24331/ijere.411329

Sartini, S. (2004). Menggali kearifan lokal nusantara sebuah kajian filsafati. Jurnal Filsafat, 37(2), 111-120. http://www.baiipos.co.id.

Sasmitatias, F., \& Kuswanto, H. (2018). The Development of Science Learning Device Based on Serukam Local Culture To Improve Students' Analytical Skill. International Journal of Educational Research Review, 3(3), 59-68. https://doi.org/10.24331/ijere.441348

Setiaji, S. (2016). Pengembangan Pembelajaran Interaktif Kolase, mozaik, dan montase untuk Calon Guru Sekolah Dasar. UNESA.

Setyadi, R., Kuswendi, U., \& Ristiana, M. G. (2019). Digital Literation Through Online Magazine In Learning Reading Comprehension In Elementary School | 97 Digital Literation Through Online Magazine In Learning Reading Comprehension In Elementary School. Journal of Elementary Education, 3(2). 
Sinlarat, P. (2016a). Sinlarat, P. Education 4.0 is More than Education.... - Google Cendekia. https://scholar.google.co.id/scholar?hl=id\&as_sdt=0\%2C $5 \& \mathrm{q}=$ Sinlarat $\% 2 \mathrm{C}+\mathrm{P} .+\mathrm{Educati}$ on $+4.0+$ is + More + than + Education. + Bangkok $\% 3 \mathrm{~A}+$ The + Secretariat + Office + of + Teacher 's + Council. $+2016 . \& b \operatorname{btnG}=$

Sinlarat, P. (2016b). Sinlarat, P. Thai education 4.0: Creative and productive... - Google Cendekia.

https://scholar.google.co.id/scholar?hl=id\&as_sdt=0\%2C5\&q=Sinlarat $\% 2 \mathrm{C}+\mathrm{P} .+$ Thai $+\mathrm{e}$ ducation $+4.0 \% 3 \mathrm{~A}+$ Creative + and + productive + educational + philosophy. + Bangkok $\% 3 \mathrm{~A}+$ Chulalongkorn+University+Press. $+2016 . \& b t n G=$

Son, B., Son, B., \& Simonian, M. (2016). An Integrated Multimedia Learning Model vs. The Traditional Face-to-Face... Journal of Educational Multimedia and Hypermedia, 25(4), $305-321$.

Suluh, H. P. I. (2018). Pengembangan media Pembelajaran Multimedia Interaktif Kesenian Pencak Dor Disekolah Menengah Pertama. UNESA.

Tajjudin, M. (2015). Pengembangan Media Belajar Berupa Buku Tutorial Sebagai Upaya Peningkatan Kualitas Menggambar Ilustrasi. Jurnal Seni Rupa, 3(1). https://jurnalmahasiswa.unesa.ac.id/index.php/va/article/view/10371

Thiagarajan. (1974). Thiagarajan, Sivasailam; And Others Instructional Development for Training Teachers of Exceptional Children: A Sourcebook. Indiana Univ., Bloomington. Center for Innovation in. Research and Development, Mc, 137-159.

Websindo. (2019a). Indonesia Digital 2019 : Internet. https://websindo.com/indonesia-digital2019-internet/

Websindo. (2019b). Indonesia Digital 2019: Media Sosial - Websindo. Web Sindo. https://websindo.com/indonesia-digital-2019-media-sosial/

Websindo. (2019c). Indonesia Digital 2019: Tinjauan Umum. Websindo.Com. https://websindo.com/indonesia-digital-2019-tinjauan-umum/

Yamin, M., \& Syahrir, S. (2020). Pembangunan Pendidikan Merdeka Belajar (Telaah Metode Pembelajaran). Jurnal Ilmiah Mandala Education, 6(1), 126-136. https://doi.org/10.36312/jime.v6i1.1121 